\title{
Analysis on Green Accounting Information Disclosure of Chemical Enterprises Under Low- Carbon Economy
}

\author{
Jun Liu ${ }^{*}$, Jiaxin Li ${ }^{2}$ \\ ${ }^{1}$ Business School (School of Quality Management and Standardization), Foshan University, Foshan 528000, Guangdong \\ Province, China \\ ${ }^{2}$ School of Accounting, Jiangxi University of Finance and Economics, Nanchang 33000, Jiangxi Province, China \\ *Corresponding author: Jun Liu, pengxj1@163.com

\begin{abstract}
In the current era of low-carbon economy, environmental governance and energy conservation have become major issues, in which chemical enterprises with high pollution and consumption have naturally attracted much attention. The disclosure of green accounting information is indispensable to the continuous development of chemical enterprises and even the whole society. Therefore, based on existing research results, this paper analyzes the existing problems and causes of green accounting information disclosure of chemical enterprises in China under low-carbon economy, and puts forward suggestions for solutions.
\end{abstract}

Keywords: Green accounting; Information disclosure; Low-carbon economy

Publication date: August 2021; Online publication: August 30, 2021

\section{Introduction}

The analysis on the implementation of green accounting information disclosure of chemical enterprises under low-carbon economy have significance.

\subsection{Research background and significance}

The ecological environment and natural resources on which social development depend on are gradually becoming exhausted. In this era, the concepts of low-carbon economy and green accounting have emerged and attracted attention. "Low-carbon economy" means making use of technical innovation, system innovation, industrial transformation, and other means, to reduce coal, oil, and energy consumptions, high pollution, as well as greenhouse gas emissions. While, mainly recording and disclosing environmental assets, environmental benefits, and the cost of environmental improvement as well as utilization, green accounting appears as a new discipline. Its combination with low-carbon economy endows it with functions like accounting and disclosing enterprises' low-carbon energy conservation activities.

In addition, the production and operation activities of chemical enterprises have significant negative impact on the environment and energy, owing to their main production technology, which involves the use of chemical methods. Therefore, this paper mainly discusses the current green accounting information disclosure of chemical enterprises. 


\subsection{Research status locally and abroad}

Domestic and foreign research status are relatively sound.

\subsubsection{Overview of green accounting information disclosure theories under low-carbon economy}

Craig and Michaela ${ }^{[1]}$ believe that enterprises' environmental cost data should be the focus of green accounting information disclosure. Bowen ${ }^{[2]}$ believes that enterprises should begin in an orderly manner from nine major projects and 46 subprojects in the process of environmental information disclosure. In addition, $\mathrm{Hu}{ }^{[3]}$ pointed out that the related theories involve the environmental value theory, sustainable development theory, stakeholder theory, etc.

\subsubsection{Problems of green accounting information disclosure of chemical enterprises under low-carbon economy}

You ${ }^{[4]}$ believes that the disclosure content of green accounting information is single. Zhou ${ }^{[5]}$ pointed out that chemical enterprises have low willingness to disclose green accounting information. Other than that, $\mathrm{Xu}^{[6]}$ and other researchers have pointed that a standard system of green accounting has not been formed. Although professionals have pointed out the existing problems, many of the problems that were put forward were from businesses of all walks and not completely targeted at chemical enterprises.

\subsubsection{Reasons for the problems of green accounting information disclosure of chemical enterprises under low-carbon economy}

Muninarayanappa [7] pointed out that the enterprise management rarely tries to make appropriate arrangements to save the environment given that they believe there is no direct relationship between investments and interests. In addition, $\mathrm{Xu}{ }^{[6]}$ pointed out that the current information disclosure lacks targeted laws and regulations' guidance. Geoffrey ${ }^{[8]}$, on the other hand, proposed that the government has failed to formulate a perfect disclosure system.

\subsubsection{Suggestions on improving green accounting information disclosure of chemical enterprises under low-carbon economy}

Modrek and other researchers ${ }^{[9]}$ pointed out that companies should try to reduce environmental penalties and improve the quality of green accounting information disclosure. Abdul and Jong ${ }^{[10]}$ believe that the government decision makers can define the scope of green accounting reports. Nie ${ }^{[11]}$ believes that China should establish and perfect relevant laws as well as regulations.

Scholars have put forward many suggestions. However, only a few came up with specific opinions based on the characteristics of chemical enterprises and combined green accounting with low-carbon economy effectively.

\section{Overview of green accounting information disclosure theories under low-carbon economy}

Based on the topic, this paper mainly discusses the theories of enterprises' green accounting information disclosure.

\subsection{Principles of green accounting information disclosure under low-carbon economy}

The disclosure of green accounting information should meet the quality requirements, such as reliability, understandability, and relevance, as well as follow specific principles. 
The disclosure should meet the mandatory principle, which means that all accounting subjects that are involved in the environmental information should fulfill the responsibility of disclosure. Moreover, green accounting information disclosure should be comprehensive. Enterprises should disclose both qualitative and quantitative indicators, as well as both static and dynamic indicators in order to disclose detailed information.

\subsection{Content of green accounting information disclosure under low-carbon economy}

The information that is disclosed should include quantitative information, such as environmental assets and liabilities, as well as qualitative information, such as the adopted depreciation method of environmental assets. As green accounting relates to various fields like environment and science, it should cover multiple information, including the positive and negative influence of enterprises on the environment.

Moreover, due to the intersection and the similar aim of green accounting and low-carbon economy, the disclosure content of green accounting should also include carbon emissions, emission indicators, and enterprises' achievements in promoting the implementation of low-carbon economy.

\subsection{Theoretical basis of green accounting information disclosure under low-carbon economy}

There are theories like the sustainable development theory and the social responsibility theory.

In 1987, the World Commission on Environment and Development issued a report titled, "Our Common Future," formally introducing the concept, "sustainable development," which is now recognized widely. Sustainable development theory implies that resources can be reused repeatedly, and the lives of future generations can be continued.

On the other hand, the concept of "corporate social responsibility" (CSR) was put forward by a British scholar, Oliver Shelton, in 1924. Domestic scholars have been paying more attention to CSR since 2006. It is generally understood that modern enterprises should emphasize their contribution to the environment, consumers, and the society while creating economic value.

Effective green accounting information disclosure under low-carbon economy would promote the realization of sustainable development. In addition to that, it would undoubtedly reflect the chemical enterprises' performance of social responsibilities, and subsequently facilitate the public to make a more comprehensive evaluation of these enterprises. In regard to all these, these theories are in fact highlighting the significance of green accounting information disclosure.

\section{Problems of green accounting information disclosure of chemical enterprises under low-carbon economy}

There are still many problems in the implementation of green accounting information disclosure among chemical enterprises.

\subsection{Unscientific modes of green accounting information disclosure of chemical enterprises}

At present, disclosure modes and carriers of green accounting information in chemical enterprises are confusing. This paper adopted the survey sampling method and selected 30 listed chemical enterprises in Shenzhen, including Shandong Haihua, Jinling Mining, and Jingyuan Coal Industry and Electricity Power Co., Ltd. to check their annual reports as well as other public information for a statistical analysis on their green accounting information disclosure modes from 2018 to 2020 as shown in Table 1. 
Table 1. Number of enterprises adopting each green accounting information disclosure mode among 30 enterprises from 2018 to 2020

\begin{tabular}{lccc}
\hline Mode $\backslash$ Year & 2018 & 2019 & 2020 \\
\hline Board report & 23 & 25 & 25 \\
Notes to the financial statements & 16 & 17 & 19 \\
Environmental report & 5 & 6 & 8 \\
Environmental accounting report & 12 & 13 & 14 \\
Important items & 3 & 3 & 4 \\
\hline
\end{tabular}

Data source: Shenzhen Stock Exchange Website

It can be seen from Table 1 that at present, China's chemical enterprises are more inclined to disclose green accounting information by board reports and notes to financial statements, which are not intuitive and independent, instead of environmental reports or environmental accounting reports, which are more direct. Moreover, various disclosure modes are mixed and there is no uniform standardization.

\subsection{Incomplete content of green accounting information disclosure of chemical enterprises}

The green accounting information disclosed by chemical enterprises is generally single, one-sided, and ambiguous. However, now, the information disclosed is much more qualitative than quantitative, and it includes mainly environmental declaration or implementation of laws and policies, such as the Environmental Protection Law. In addition, the division of accounting items of most chemical enterprises are not scientific. For example, sewage treatment equipment and greening equipment that are related to green accounting are directly classified as fixed asset items instead of being in subdivisions. Meanwhile, activity information relating to low-carbon economy, such as carbon energy saving, is not separately listed.

\subsection{Low motivation of green accounting information disclosure of chemical enterprises}

The green accounting information disclosure of chemical enterprises is perfunctory at large. Enterprises lack the initiative and willingness to disclose. Additionally, most chemical enterprises do not have a separate green accounting and supervision system, thus naturally there is no separate organization that is responsible for green accounting information disclosure. It can be seen that at present, chemical enterprises do not pay enough attention to green accounting and still classify it under the same discipline as other traditional financial accounting information disclosure.

\subsection{Lack of high-level green accounting professionals in chemical enterprises}

At present, the research on green accounting information disclosure is mainly conducted by senior or highlevel professional scholars in the industry, and in chemical enterprises, there are inadequate staffs who are really engaged in green accounting information disclosure. In addition, green accounting itself is complex, where only a few personnel in chemical enterprises who are engaged in this information disclosure can master this responsibility. The basic level and low quality of enterprises' personnel are also part of the problems.

\section{Reasons for problems of green accounting information disclosure of chemical enterprises under low-carbon economy}

There must be reasons for the existence of these problems, thus this paper briefly analyzes the causes of the problems. 


\subsection{Unclear requirements of laws and regulations}

The main cause of the problem lies in the lack of laws and regulations. At present, the laws and regulations in relation to the environment field, ecological field, and accounting field do not specify which modes of green accounting information disclosure should be adopted by enterprises; thus, enterprises choose the modes by their own will. In contrast, the Securities Law of the People's Republic of China has made it clear that listed companies should continue disclosing accounting information and has specified the disclosure form as well as the time range to ensure that listed companies would disclose major issues, including their asset structure, operating profit, and changes to their accounting information on a regular basis. This shows the importance of laws and regulations in regard to the disclosure of accounting information.

\subsection{Incomplete green accounting theories and accounting standards}

In February 2006, the Ministry of Finance in China issued the $30^{\text {th }}$ Accounting Standards for Enterprises Presentation of Financial Statements, which stipulates the details of enterprises' financial report information disclosure. Theories such as relations between various financial statements gradually perfect the content of financial statements for information disclosure. The reason why the focus and validity of the content of green accounting information disclosure of chemical enterprises are not satisfactory is due to imperfect theories and accounting standards.

Only a few local experts and scholars, such as Liu Jinbin and Zhang Benyue, have been studying the green accounting theory and system so its theoretical research level is still low. Additionally, China also lacks accounting standards and guidelines for green accounting information disclosure.

\subsection{Lack of environmental awareness and external supervision of chemical enterprises}

On the one hand, the supervision of agencies, including accounting, environmental protection, and legal agencies has a laissez-faire attitude. On the other hand, many chemical enterprises only pay attention to immediate gains and losses without having environmental awareness. Chemical enterprises have an understanding that a large sum of investment is required when committing to conserve the environment or resources. Although environment and energy conservation can bring benefits to the sustainable development of chemical enterprises, in the short term, there are only minimal economic benefits. Therefore, enterprises own short-sighted ideas and consider this as an investment reservation.

\subsection{Unreasonable green accounting talent training system}

Several chemical enterprises do focus on the training of personnel for green accounting information disclosure; thus, there are a few staffs who can master the disclosure of green accounting information in these enterprises. The accounting training system in colleges and universities is imperfect, and due to the complexity of green accounting, accountants need to spend a long time to learn the relevant skills. Although most colleges and universities are committed to cultivate innovative talents, they generally do not offer separate courses that are related to green accounting, as most of them are not able to educate the students in regard to green accounting in a comprehensive and detailed way.

\section{Suggestions to improve the green accounting information disclosure of chemical enterprises under low-carbon economy}

There is a need to approach from various aspects to improve the information disclosure system. 


\subsection{Completing the provisions of laws and regulations under low-carbon economy}

Government departments should make unambiguous legal and specification files as soon as possible. Related departments can delimit different hierarchy and standards according to the impact on the environment and resources, the scale, and the social influence of different enterprises. They should also stipulate which disclosure form that chemical enterprises at different levels should choose and the penalty for those enterprises that fail to comply to the provisions. In addition, the government ought to investigate and penalize companies openly on a regular basis. They should also consider publicizing the punishment or commendation periodically in order to ensure the enforcement of laws and regulations as well as to emphasize on green accounting information disclosure.

\subsection{Improving the theoretical system and accounting standards of green accounting information disclosure}

"Leaders" in the field and accounting industry associations or other organizations should make full use of the complementary relationship between low-carbon economy and green accounting, emphasize the prospect of green accounting, then mobilize the enthusiasm of experts and scholars for theoretical research on green accounting information disclosure. During the research process, professionals can also communicate with foreign experts to strengthen international exchanges and cooperation. Moreover, organizations which formulate norms in the industry can arrange personnel to visit chemical enterprises for on-site evaluation. Based on the actual production situation of chemical enterprises, the accounting standards of green accounting information disclosure can be formulated.

\subsection{Strengthening the effective guidance for enterprises}

In the recent ten years, the energy reserve situation is not optimistic. When energy is exhausted, many chemical enterprises would lose basic raw materials and products, thus their survival cannot be guaranteed. Chemical enterprises should be guided to raise their awareness on the particularity and importance of green accounting information disclosure when being told these things. In addition, now that the low-carbon economy concept has been recognized by the majority, related agencies should help enterprises to understand that green accounting information disclosure would not only fulfill their social responsibility, but also improve the corporate image in order to strengthen their willingness to implement green accounting information disclosure.

\subsection{Promoting the intensity and rate of professional personnel training}

The government should provide funds and manpower to publish professional books on green accounting for accountants to learn. Accountants can then be guided by this to fully understand the importance of green accounting information disclosure by means of the sense of identity gained from the low-carbon economy and the relationship between them so that they can actively update their knowledge structure. Colleges and universities should also try to set up special courses on green accounting as soon as possible to cultivate students' ideas and application skills in green accounting information disclosure. Chemical enterprises' managers should not only recruit professional staffs, but also provide more opportunities for staffs to learn and receive trainings regarding green accounting information disclosure.

\section{Funding}

This study was supported by Guangdong Philosophy and Social Science Planning Project "Collaborative Research on Carbon Emission Reduction Approaches and Policies in the Guangdong-Hong Kong-Macao 
Greater Bay Area Based on Systematic Science Theory” (Project number: GD17CYJ08).

\section{Disclosure statement}

The authors declare that there is no conflict of interest.

\section{References}

[1] Deegan C, Rankin M, 2018, The Materiality of Environmental Information to Users of Annual Reports. Accounting, Auditing and Accountability Journal, (10): 562-83.

[2] Howard B, 2019, Social Responsibility of Entrepreneurs. British Accounting Review, (1): 1-18.

[3] $\mathrm{Hu} \mathrm{B}, 2019$, Theoretical Basis of Enterprise Environmental Accounting Information Disclosure. Contemporary Accounting (02): 23-6.

[4] You X, 2018, Design of Enterprise Environmental Accounting Information Disclosure Model from the Perspective of Low-carbon Economy. Communication of Finance and Accounting, (16): 11-4.

[5] Zhou H, 2017, Analysis on Environmental Accounting Information Disclosure of Chemical and Pharmaceutical Enterprises - A Case Study of Zibo Dongda Chemical Co., Ltd. Communication of Finance and Accounting, (25): 13-7.

[6] Xu S, Zhang S, Jian X, et al., 2019, Environmental Accounting: Theoretical Review and Research Prospects. Finance and Accounting Monthly, (03): 78-85.

[7] Muninarayanappa M, 2017, Mad Users' World - Paradox of Users and Polluters!! - Make A Breakthrough in Environmental Accounting. European Scientific Journal, : 490-504.

[8] Frost GR, 2017, The Introduction of Mandatory Environmental Reporting Guidelines: Australian Evidence. Abacus, (2): 190-216.

[9] Modrek AS, Prado J, Bready D, et al., 2018, Modeling Glioma with Human Embryonic Stem CellDerived Neural Lineages. Methods in Molecular Biology, (11): 324-9.

[10] Masud MAK, Jong DK, 2017, Analysis of Environmental Accounting and Reporting Practices of Listed Banking Companies in Bangladesh. Sustainability, (10): 62-9.

[11] Nie J, 2018, Research on Environmental Accounting Information Disclosure of Heavily Polluting Listed Companies - Based on the Background of Low-Carbon Economy. Friends of Accounting, (05): $18-22$. 